\title{
Laughter as a Rational and Irrational Phenomenon in Harold Pinter's The Hothouse
} DR. ERCAN GÜROVA*

\begin{abstract}
Harold Pinter's 1958/1980 play The Hothouse presents the laughter effect by making use of rational and irrational approaches of comic. In its absurdist tone, the two act play aims to mock hierarchical power structures with its setting and characters. With its witty and playful dialogues, the play creates the laughter effect by amalgamating the social and psychological functions of laughter. This article seeks to study Pinter's play closely from the use of rational and irrational way of the laughter effect. Using the theories of Henri Bergson's laughter concept as a rational comic approach and Freud's joke concept as an irrational comic approach, this study shows how laughter effect is constructed in Pinter's play.
\end{abstract}

Keywords: Harold Pinter, The Hothouse, laughter, rational, irrational

\section{HAROLD PINTER'IN THE HOTHOUSE TIYATRO OYUNUNDA RASYONEL VE İRRASYONEL BIR OLGU OLARAK GÜLME}

\section{Öz}

Harold Pinter'in 1958/1980 tarihli The Hothouse tiyatro oyunu komikliğin rasyonel ve irrasyonel yaklaşımlarından yararlanarak bir gülme etkisi meydana getirir. Absürt bir tonla, bu iki perdelik oyun zaman/mekân ve karakterleriyle hiyerarşik iktidar yapılarını alaya almayı amaçlamaktadır. Esprili ve eğlenceli diyaloglarıyla oyun gülmenin sosyal ve psikolojik işlevlerini bir araya getirerek bir gülme etkisi yaratmaktadır. Bu makale Pinter'in tiyatro oyununu gülme etkisinin rasyonel ve irrasyonel kullanımından yola çıkarak yakından incelemeyi amaçlamaktadır. Henri Bergson'un rasyonel komik yaklaşımında gülme kavramı ile Freud'un irrasyonel komik yaklaşımı olan şaka kavramını kullanan bu çalışma, Pinter' ın oyununda gülme etkisinin nasıl oluşturulduğunu göstermektedir.

Anahtar sözcükler: Harold Pinter, The Hothouse, gülme, rasyonel, irrasyonel

\section{INTRODUCTION}

s one of the most influential contemporary British playwrights, Harold Pinter
produced several higly acclaimed works such as The Birthday Party (1957), The
Homecoming (1964) and Betrayal (1978). Born in a working class family with Jewish backgrounds in 1930, he had to go through disturbing experiences such as fear of war and insecurity during his early years (Gandhi, 2010, p. 110). Therefore, it comes as no surprise that he wrote about power dynamics, corruption, preoccupation with authority and abuse of power especially in The Hothouse (1958/1980), The Dumb Waiter (1959), One for the Road (1984), The Birthday Party, and New World Order (1991). Even though Pinter was precoccupied with government

\footnotetext{
* Ankara Ün. Yabancı Diller YO, ercangurova@hotmail.com, orcid: 0000-0001-5446-9013 
policies and institutional authority issues, his early plays were mostly concerned with familial and sexual politics (Wong, 2013, p. 2). The only exceptions to this generalisation were The Birthday Party and The Hothouse. Plays such as The Room (1957), The Lover (1962), and The Homecoming (1964) mostly deal with the theme of communication or lack of communication.

The Hothouse, first written in 1958 and later published and performed in 1980, takes place in a mental institution in the country which is described as 'rest home' by the staff and it displays the "institutional application of violence" through the brutal treatment of staff against patients (Peacock, 1997, p. 140). The inmates who are kept locked in freezing rooms in this mental house have numbers rather than names. The only names the reader is provided are the staff whose leader is an ex-army officer called Roote. The other names of this hierarchical organisation are "grotesquely and monosyllabically" named as Lush, Hogg, Budd, Tuck, Dodds, Tate, Peck, Gibbs, lamb, Cutts, Tibb and Lobb (Esslin, 1976, p. 102). In this "grim, Orwellian fantasy", gruesome things take place such as family members of the patients have to breach security in order to reach the inmates and when the patients die, their families are not informed about the death (Batty, 2014, p. 34). Furthermore, the conditions under which the patients live contribute to the general atmosphere of institutional oppression. The soundproof chambers which are equipped with electrodes and monitored remotely by control rooms and the wild cross-examinations which cause the demise of patients exemplify this oppression.

Even though the play is set in a mental institution, the reader never has the opportunity to see the patients. Instead, the central focus is mostly on the power structure and its relationship with the individual. In other words, "the personal and the political are intertwined" as a reverberation of Pinter's vision of local totalitarianism which foregrounds the process of liberalisation, surveillance and demand for human freedom (Quigley, 2009, p. 10). The history of the power hierarchy goes back to the founding father of the establishment in the play. As the current head of the institution, Roote is seen as the murderer of one inmate and the father of another one; however, the discovery of these truths is revealed by comical subtextual clues and through the dialogues between Roote and his inferiors. This study focuses on how the laughter effect in The Hothouse is constructed with the combination of the rational and irrational approaches of comic by using Bergon's and Freud's laughter and joke concepts as a springboard. The reason why the arguments of these two scholars is chosen is based on the idea that both names are significant contributors to the laughter phenomenon; the former one is the leading advocate of the explanation of laughter in a rational sense and the latter one prefers to deal with it from an irrational perspective.

\section{LAUGHTER AS A RATIONAL PHENOMENON}

The study of the laughter phenomenon traces back to the Ancient Greek philosophers such as Socrates, Plato and Aristoteles. The overall ancient approach to laughter and comic is negatory and condescending as these concepts are not in par with the human ideals of being virtuous and moderate (Coştu, 2020, p. 5). When it comes to the Middle Ages, the deprecating attitude to laughter and comic is intensified and it is banned in all official circles with the exception of 
festivals and carnivals (Bakhtin, 2001, p. 92). Even though the cultural and artistic gain of the Renaissance period lays the groundwork for more favorable and embracing approach towards laughter, it is the 20th century's pioneers such as Bergson and Freud who are able to reveal the social and psychological layers of laughter as a phenomenon in detail.

In contemporary theories of laughter, there are two main perspectives to the laughter phenomenon and they differ on the idea that laughter is whether a rational or an irrational phenomenon. The rational aspect towards laughter argues that laughter is the embodiment of the rational faculties of the human mind and any perception of inconsistency or discordance which bears no value of authenticity functions as a comic stimulus in people's minds. In such cases, it is argued that human mind notices an inaccuracy and corrects it with laughter (Cebeci, 2017, p. 17).

In his book titled Laughing: A Psychology of Humour Norman Holland underlines the social function of comic and laughter effect by presenting the idea that laughter effect bears a mission of social correction and a longing for going back to a desired state; furthermore, it brings a sort of positive affirmation of the sociability or sometimes social revolutions. It also rejects the idea that comic and laughter effect is derogatory and inferior (Norman, 1982, p. 92-103). In short, Holland elaborates on the social aspect of the lauhter phenomenon and his categorisation is based on these social functions of the concept.

One of the leading advocates of the laughter as a rational phenomenon is Henri Bergson, a 20th century French philosopher. In a book titled Laughter: An Essay on the Meaning of the Comic (1900), Bergson theorizes the concept of laughter by pointing out what laughter means and what features help to reveal the laughter effect in humans. In his explanations, Bergson puts an emphasis on the social function of laughter.

According to Bergson, there are some underlying rules which determine the laughter effect among people and the first one is called rigidity. As life can be described as a state of constant flux and change, anything which disrupts the elasticity of life, any interruption which conceals animation and motion of life contributes to the formation of laughter (Bergson, 1913, p.21). In other words, laughter is regarded as a pause or station in this incessant flow of life movements. This idea of rigidity is illustrated in the "machine" metaphor: "The attitudes, gestures and movements of the human body are laughable in exact proportion as that body reminds us of a mere machine" (Bergson, 1913, p.28). The image of machine and human are intertwined as to produce the laughter effect and the more life movements resemble those machine-like features, the higher the laughter effect becomes (Bergson, 1913, p.31).

The rigidity feature can be uncovered in the play with certain characters and scenes. The most rigid example is Roote, who is the leader of the mental institution and an ex-army officer. Being the administrator of the 'rest home' with an army background, Roote displays strict manners in his general appearance and in the dialogues with Gibbs, his most senior assistant, which reminds the reader of a machine-like rigidity. This example of rigidity in the main character contradicts the elasticity of life, which eventually gives rise to laughter in the text. The strict hierarchical relationship between Roote and Gibbs, the way they address each other and the serious matters they deal with are disrupted and diluted with the help of what Bergson calls "inner suppleness of 
life" (Bergson, 1913, p.44). While answering his superior's questions about the daily and weekly routines of patients, Gibbs unfolds the fact that Roote is not aware of what is really going on in the institution. For example, in one of his routine meetings with Gibbs, he finds out that one of the patients has died and another one has just had a baby. Another example is how Roote does not remember which patient he has interviewed with because of the numbers the institution gives to the patients, which has been a rule established earlier and followed by Roote himself as well.

Even though Roote leaves an impression that he has everything under control in the institiution with his great leadership, it turns out that long-established rules are violated and this breach of rules occur in spite of Roote's experienced and unwavering administrative skills. The moment his flaws are disclosed, Roote starts lecturing about how impeccable an institution they have been running for decades. Furthermore, he gives examples of so-called heroism from his predecessor: "As my predecessor said, on one unforgettable occasion: 'Order, gentlemen, for God's sake, order!'I remember the silence, row upon row of electrified faces, he with his golden forelock, his briar burning, upright and commanding, a soldier's stance, looking down from the platform." (Pinter, 1991, p. 95) His using a boastful language about past practices and its sharp and unreal contrast with today's deplorable portrayal of the institution serves nothing but more laughter effect because of the increasing contradiction between rigidity and elasticity in the text.

Another rule which helps evokes laughter in the audience is what Bergson calls absentmindedness. It is one of the most common and natural components of the act of laughing and its effects become intensive when we see it "springing up and growing before very eyes" (Bergson, 1913, p. 12). Being the director of the institution, Roote is expected to be in charge and aware of significant developments such as the death of a patient or the delivery of a baby. On the contrary, he is neither able to remember the appearance of the patients, nor is he able to remember the time he has signed the death certificate of the recently died patient. In the long dialogues with Gibbs on how and when a patient has died, the reader is able to observe how absentmindedness in the character is formed and serves to bring about the laughter effect. The rule of absentmindedness also functions as an elasticity of life and when it combines with rigid manners or speech in the text, laughter effects become unavodiable:

Roote: He's dead, you say?

Gibbs: Yes, sir.

Roote: Then why wasn't I told? It's your job to keep me informed of all developments in this building, no matter how slight, no matter how trivial. I demand an answer. Why wasn't I told?

Gibbs: You signed the death certificate, sir.

Roote: Did he get a decent burial?

Gibbs: Oh, very decent, sir.

Roote: I don't see why I wasn't invited. Who said the last words over him?

Gibbs: There were no last words, sir. (Pinter, 1991, p. 91)

A third rule which contributes significantly to laughter in the audience is repetition, according to Bergson. The Hothouse provides a considerable number of repetitive patterns, which has a certain effect on its comicality. Bergson elaborates on this effect of repetition on laughter in 
his work by arguing that repetition itself without a context is not effective; however, when it becomes a specific symbol of a play, it makes the audience laugh (Bergson, 1913, p. 73). He comes up with this rule of "comic repetition of words" which have a comical effect when performed on stage and explains its logic as follows: "In a comic repetition of words we generally find two terms: a repressed feeling which goes off like a spring, an idea that delights in repressing the feeling anew" (Bergson, 1913, p. 73).

One of the most commonly used repetitive words throughout the play is sir. The frequent use of the word sir by Gibbs in his conversation with Roote helps to deteriorate the rigidity of Roote's status. Even though it is quite prevalent to hear the word sir in any conventional hierarchical setting, hyper-occurence of the word (seventy times) whether appropriately or not creates a mocking manner which eventually causes softening of Roote's stiffness.

Roote: Gibbs.

Gibbs: Yes, sir?

Roote: Tell me...

Gibbs: Yes, sir?

Roote: How is 6457 getting on?

Gibbs: 6457, sir?

Roote: Yes.

Gibbs: He's dead, sir. (Pinter, 1991, p. 86)

With the overuse of the word sir at all times, Roote's formal position and his superiority is shaken and the rigid image he tries to establish is eroded. In addition to repeated words such as sir, Pinter makes use of questions and accusations as repetitive patterns in the play. Roote's suspicious manners accompanied with bizarre questions are foregrounded especially in his conversations with Gibbs. His constant accusations against Gibbs and the density of similar questions can also be interpreted as his fear of losing power and authority. Producing a barrage of questions, Roote seems to hide something he lacks or tries to conceal some of his blind spots. As Pinter comments on conversations in his Writing for the Theatre speech at the National Student Drama Festival in Bristol in 1962, "One way of looking at speech is to say that it is a constant strategem to cover nakedness" (Pinter, 1991, p. xiii). While he desperately strives to fill the void to sustain his alleged supremacy and possessive behaviour, excessive use of questions and accusations lead to a comic effect. For instance, Gibbs's standing too close to Roote, Roote's misunderstanding almost everything and asking questions to change the subject incessantly are some common scenes throughout the play. In fact, there are several variations of the questions of "What's the matter with you?" and "Who do you think you are?". The main character's suspicious nature as a defense mechanism is explained by Cahn as follows:

Pinter's characters live in perpetual suspicion, regarding both familiar figures and strangers with trepidation. His characters are also protective of what they see as their own, objects and territory over which they can assert sovereignty. As a result of this state of mind, his characters are forever on guard against invasion, both physical and psychological. They are always nervous that whatever few rights and possessions they claim may be snatched away, leaving them even more alienated. (Cahn, 1993, p. 2) 
In addition to recurrent repetitions such as certain words, expressions, questions or sequences of dialogues, the laughter effect can also be created with the help of inversion. As stated by Bergson, inversion takes place when a situation is reversed and the roles are inverted, which in return helps to generate comicality (Bergson, 1913, p. 94). When Roote, the person who seemingly has the absolute power and authority over the others, becomes the victim of his subjects or when the hierarchical relationship between Roote and Lobb, the senior manager of the Ministry, is reversed, the comical effect is unveiled. Furthermore, for the most part of the play, Roote urges his assistants to investigate the suspicious death of a patient and a new born baby of another patient as a result of rape. At the end of the play, it turns out that Roote himself is the perpetrator of the reported murder and the rape, which leads to his downfall. The illustration of reversed roles is depicted as the murderer becomes the murdered or the brutal becomes the subject of another brutality. Despite the fact that there seems to be cruelty, violence and tyranny on the part of Roote, his demise in the hands of his suppressed and tortured patients help to create a comical effect at the end of the play.

Another rule which brings about "far-reaching" comic effect on audience is what Bergson calls transposition (Bergson, 1913, p. 121). It is basically a sort of paraphasing the same topic with a different mood or style in a different context. Bergson defines this feature as follows: "A comic effect is always obtainable by transposing the natural expression of an idea into another key" (Bergson, 1913, p. 123). The dialogue between Roote and Miss Cutts, one of the staff in her 30s, is presented as a typical example of transposition in the play. The strict hierarchical structure and Roote's authoritative manner is undermined by informal, rather vulgar behaviour and questions of Miss Cutts, which leads to a comic effect in the end. To illustrate, Miss Cutts's insistence on asking whether she looks feminine enough in the eyes of men is the consequence of transposing the "solemn" into "familiar" (Bergson, 1913, p. 123).

While explaining the rules of the comic effect, Bergson puts forward the features of degradation and exaggeration. Degradation happens when something which used to be respected once turns into something insignificant and contemptible (Bergson, 1913, p. 124). A tangible example of this feature can be found in the derogating hegemony of Roote and his cartooning image as a leader in an institiution which gets out of control in the end. Roote's delusional belief of his absolute leadership as he gives seemingly great examples from his predecessors, his unshakeable faith in the significance of the institution he rules now falls apart and he becomes the victim of his misdeeds and mismanagement.

Exaggeration is as effective as degradation when it comes to the formation of laughter "when prolonged and especially systematic" (Bergson, 1913, p. 125). The hyperbolic use of Roote's absentmindedness and forgetful behaviour; excessive use of some expressions by Gibbs, Roote and Miss Cutts; overstated mission of the institution as "instilling confidence in every patient"; Roote's exaggerated response against the new born baby and his reactions of being the ultimate leader as in the examples of "I'm a delegate! I was entrusted! I'm a delegate! I was appointed! ... I am authorised!" are among the most prevalent examples of exaggeration in the play. 


\section{LAUGHTER AS AN IRRATIONAL PHENOMENON}

In addition to the laughter theory which regards laughter as a rational phenomenon, there is another approach conceptualized as "laughter as an irrational phenomenon" which is pioneered by Sigmund Freud, the Austrian-born neurologist and founder of psycho-analysis. Accoording to Freud, laughter represents a transition from the rational to the irrational (Cebeci, 2017, p. 17). One should bear in mind that the "rational faculty" does not disappear completely when the comical effect is revealed; it is rather succumbed to the comicality for a short and temporary time. Therefore, the act of laughing does not pose a threat to rational thinking, nor does it have such a function (Gurewitch, 1975, p. 22).

In his books titled Jokes and Their Relations to the Unconscious (1905) and Humour (1928), Freud argues that laughter emerges from a conflict between an ego-controlled behaviour and an idoriginated behaviour on a physiological level, whereas on a psychological level; it symbolizes a "regression" in the service of ego. Freud elaborates on this by saying that laughter is the discharging or unloading the accumulated energy of an unrealized ambition in humans in a pleasurable way (Holland, 1982, p. 47). Furthermore, laughter effects is resembled to a "play relation" as the superego of the person who makes jokes is believed to accumulate some of the energy which belongs to ego of that person. Therefore, the interaction superego establishes with ego over the new power sharing conveys a feature of "play relation" (Cebeci, 2017, p. 27).

What Freud attempts to do is to disclose the relation between jokes and the unconscious with the help of case studies. As jokes are a subcategory of the comic for Freud, the research on jokes certainly makes contributions to the field of the comic and laughter (Freud, 1996, p. 211 ). According to his approach, jokes can be explained on the basis of aggression and sexuality (Freud, 1996, p. 128). In a conversation among Roote, Gibbs and Lush on why Roote should make a Christmas speech for the patients, Roote seems to be reluctant to deliver a speech. This hesitant move makes Lush, another staff member, question his authority as a leader, which is followed by his suggestion to quit the position. This suggestion and the following accusations of Lush about Roote's incapabilites at his current status triggers an aggression attack. Roote starts shouting and hitting Lush in the stomach. However, this wave of aggression and violence is disrupted by his impotent and ridiculous words such as his repetitive use of "I'm a delegate! I was entrusted! I'm a delegate! I was appointed!.. Delegated! Appointed! Entrusted!.. I am authorised!" (Pinter, 1991, p. 132). Hence, the Freudian conflict between his ego-controlled behaviour (Roote's unwavering authority, his undisputed superiority and his calm manner) and id-originated behaviour (his losing control, aggressive and violent acts) helps create a comical effect with the help of Roote's unwarranted reactions.

A similar example of an aggression scene can be found in the dialogue between Roote and Gibbs where Roote starts accusing him of setting a plot of murder. Even though Gibbs explains his presence regarding the Christmas speech, Roote keeps speculating on his future motives in order to remove him from his status. While making his accusations fiercely, Roote turns into an immature and humorous figure because of the way he justifies his arguments to convince the others: 
Roote: What do you want?

Gibbs: I came to hear your Christmas speech, Colonel.

Roote: You're sure you didn't come here to murder me?

Gibbs: Murder you?

Roote: Yes, wasn't that why you came?

Gibbs: Certainly not. What an idea.

Roote: Yes, you did. I can see it in your eyes! ...

Gibbs: I did no such thing.

Roote: You went cross-eyes, man, don't argue with me. Guity! It was written all over your face.

Gibbs: This is ridiculous. (Pinter, 1991, p. 133)

In addition to aggression, Freud considers the topic of sexuality to be the basis of laughter. Just like the dreams which reveal the unconscious, laughter is also displayed through the agency of an id-ego conflict on issues of sexuality (Freud, 1996, p. 197). In the scene where Roote and Cutts discuss their relationship, Cutts complains about why he thinks she is not feminine enough for him. When Roote responds to her by saying that she is feminine enough for him, Cutts demonstrates a backlash:

Cutts: Or perhaps... perhaps it's because you think you're not masculine enough.

Roote: I am!

Cutts: Perhaps you're not.

Roote: You can't want me to be more masculine? (Pinter, 1991, p. 136-137)

As can be seen from the dialogue, the conflict between the ego (Roote's defence of his masculinity as a potent man) and the id (his wounded masculinity and efforts to prove it desperately) contributes to a comical effect and laughter in the play.

\section{CONCLUSION}

The laughter effect in Pinter's The Hothouse is formed with the dual use of both the rational and the irrational approaches of comic. According to what Bergson suggests regarding the rational approach to comic, laughter has a social function and there are some certain rules which determine the laughter effect on the audience. Some of the most common rules that can be found in the play are rigidity, absentmindedness, repetition, inversion, transposition, degradation and exaggeration. By pointing out sociological aspect of the comic, Bergson puts an emphasis especially on the contradiction between the mechanical rigidity and the elasticity of life. The tension between these two concepts and the flux from the rigid one to the flexible one can easily be observed in The Hothouse. Most of the Roote-Gibbs and Roote-Miss Cutts dialogues are very illustrative of this fact. In short, the created tension between mechanical rigidty and elasticity and the course of this tension helps to bring forth a laughter effect in the play.

The other side of the laughter effect in The Hothouse is provided with what Freud defines as the irrational aspect of the comic. Even though the rational thinking does not disappear completely, it is suspended for a short time, which lays the groundwork for an irrational approach. The psychological function of this laughter effect is based on the conflict between the egocontrolled and id-originated behaviour patterns. It is followed by a discharging or an unloading of 
some accumulated energy, which leads to laughter. Thus, the laughter effect in the play is presented on the basis of motives such as aggression and sexuality. The aggressive behaviour patterns between Roote and Gibbs and the sexuality topic between Roote and Miss Cutts are very descriptive of these motives. In conclusion, laughter in The Hothouse is created with the binary use of the rational and irrational approaches to comic. The former one constitues the social function of the comic and the latter one represents the psychological function of it. Hence, The Hothouse is a successful example of this combined function of laughter in the contemporary British Drama.

\section{BIBLIOGRAPHY}

Bakhtin, Mikhail. (2001). Karnavaldan Romana, Edebiyat Teorisinden Dil Felsefesine Seçme Yazılar. Trans. Cem Soydemir. İstanbul: Ayrıntı.

Batty, Mark Taylor. (2014). The Theatre of Harold Pinter. London: Bloomsbury.

Bergson, Henri. (1913). Laughter: An Essay on the Meaning of the Comic. Trans. Cloudesley Brereton and Fred Rothwell. New York: The Macmillan Company.

Cahn, Victor L. (1993). Gender and Power in the Plays of Harold Pinter. New York: St. Martin's Press.

Cebeci, Oğuz. (2017). Komik Edebi Türler. İstanbul: İthaki.

Coştu, Feyza Ceyhan (2020). “Gülme Üzerine Bir Deneme: Bergson ve Freud.” Felsefe Dünyası Dergisi 71, 135-154. Access 14.05.2021. https://dergipark.org.tr/tr/pub/ felsefedunyasi/issue/58120/731253

Esslin, Martin. (1976). Pinter: A Study of His Plays. New York: The Norton Library.

Freud, Sigmund. (1996). Espriler ve Bilinçdışı ile İlişkileri. İstanbul: Payel.

Gandhi, Lingaraj. (2010). “Critiquing Power Dynamics: A Reading of Harold Pinter's The Hothouse." Journal for Bloomers Research. 3,1, 110-120. Access 17.05.2021. https://citeseerx.ist.psu.edu/viewdoc/download?doi=10.1.1.932.639\&rep=rep1\&type=pdf

Gurewitch, Morton. (1975). Comedy: The Irrational Vision. Ithaca: Cornell University Press. Holland, Norman. (1982). Laughing: A Psychology of Humor. Ithaca: Cornell University Press.

Quigley, Austin. (2009). "Pinter, Poltics and Postmodernism." The Cambridge Companion to Harold Pinter. Ed. Peter Raby. Cambridge: Cambridge University Press. 7-26.

Peacock, Keith. (1997). Harold Pinter and the New British Theatre. London: Greenwood Press.

Pinter, Harold. (1991). Harold Pinter: Plays. London: Faber and Faber.

Wong, Jane and Yeang Chui. (2013). Affirming the Absurd in Harold Pinter. New York: Palgrave Macmillan. 


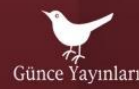

Prof. Dr. Önder Göçgün

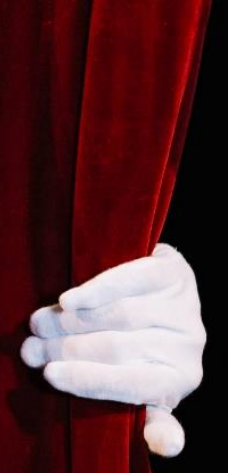

TIYYATRO DENEN HAYAT

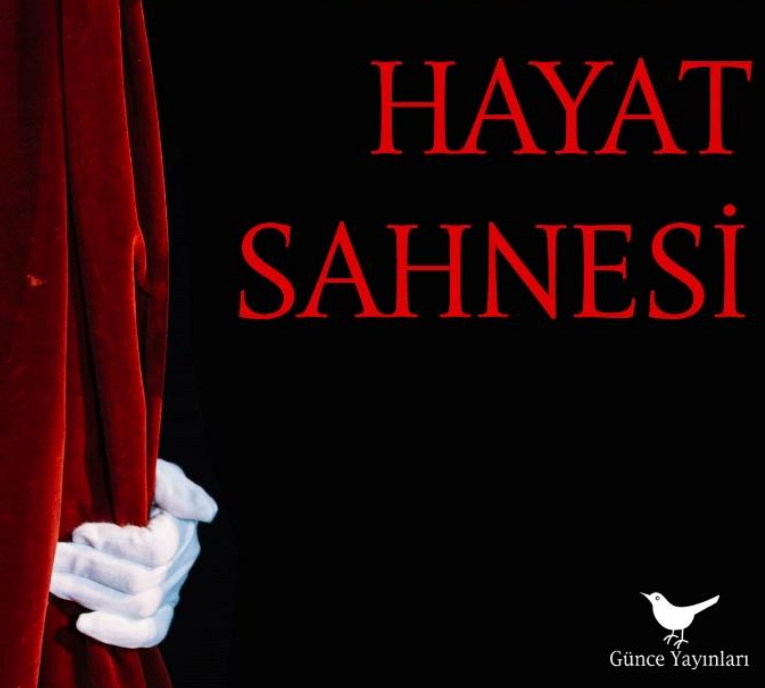

MUIIARREM DAYANC OKTAY YIVLI MACI'I BALIK MAIIMU'I BABACAN SLVIM SLERMEI
YASFMIN MUMCU BLDI் KOÇАKOĞLU NILÜLLLR ILLHAN MAKSUT YIĞITBAS SLL $\triangle M I I L \Lambda N$

\section{EDEBIYATINDA

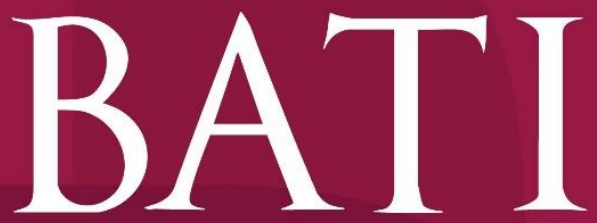 \\ EDEBIYATINDA
AKIMLAR \\ $\underset{\substack{\text { EDEBIYATINDA } \\ \text { AKIMLAR }}}{\mathrm{B} A T \mathrm{~T}}$}

editör

OKTAY YIVLI

HATICE FIRAT

YASEMIN MUMCU

OKTAY YIVLI

OĞUZHAN KARABURGU

BERNA AKYÜZ SIZGEN

NILÜFER ILHAN
ÜMMÜHAN TOPÇU

SEFA YÜCE

HANIFI ASLAN

METIN AKYÜZ

MEHMET SÜMER
YAKUP ÖZTÜRK
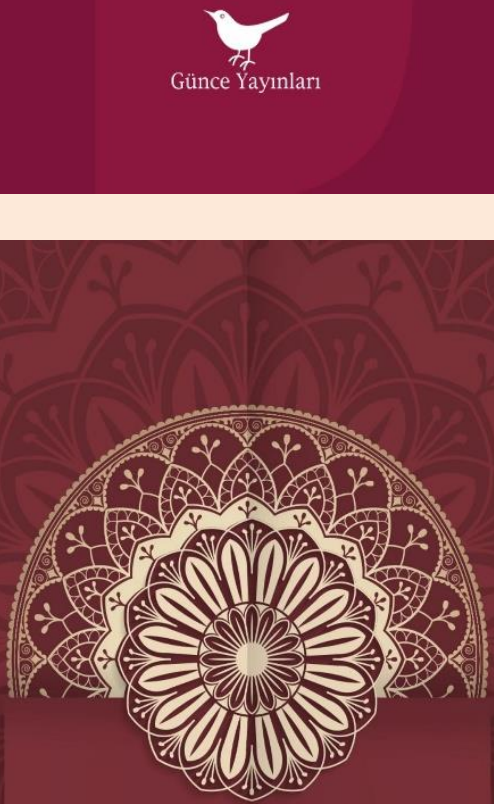

PROF. DR. ÖNDER GÖÇGÜN

$$
\begin{gathered}
\text { Türk } \\
\text { Tasavvuf } \\
\text { Siini }
\end{gathered}
$$

AÇIKLAMALI VE YORUMLU ÖRNEKLERLE 